\title{
ESTERIFIKASI DAN DEASIDIFIKASI MINYAK JELANTAH SEBELUM PEMBUATAN BIODIESEL DENGAN KATALIS ABU TONGKOL JAGUNG
}

\author{
R. E. Y. Adu \\ Fakultas Pertanian, Universitas Timor, Kefamenanu, Indonesia \\ Email: adoe.risna@yahoo.com
}

\begin{abstract}
ABSTRAK
Esterifikasi dan deasidifikasi minyak jelantah melalui netralisasi alkali sebelum pembuatan biodiesel menggunakan abu tongkol jagung sebagai alternatif katalis basa telah dilakukan untuk menurunkan kandungan asam lemak bebas hingga memenuhi kondisi transesterifikasi yang diinginkan. Esterifikasi dilakukan dengan mereaksikan minyak jelantah dan metanol dengan rasio volume tertentu dan katalis asam $\left(\mathrm{H}_{2} \mathrm{SO}_{4}\right)$ pada suhu $50^{\circ} \mathrm{C}$ selama 4 jam. Deasidifikasi dilakukan dengan menambahkan larutan $\mathrm{NaOH} 0,5 \mathrm{~N}$ (alkali berlebih sebanyak 15\%) pada suhu $60^{\circ} \mathrm{C}$ selama 30 menit.Esterifikasi minyak jelantah menggunakan katalis asam sebelum transesterifikasi dengan katalis abu tongkol jagung meningkatkan efisiensi konversi asam lemak bebas secara signifikan $(92,69 \%)$ pada kondisi rasio volume metanol/minyak $25 \%$ dan konsentrasi katalis asam $0,5 \%$ selama 4 jam reaksi. Deasidifikasi minyak hasil esterifikasi yang memiliki konten FFA 2,29 mg KOH/g minyak melalui netralisasi alkali pada suhu $55^{\circ} \mathrm{C}$ menggunakan konsentrasi alkali $0,8 \mathrm{~N}$ menurunkan konten asam lemak bebas hingga $0,47 \mathrm{mg} \mathrm{KOH} / \mathrm{g}$ minyak. Hasil analisis terhadap hasil transesterifikasi menunjukkan bahwa komponen biodiesel dari minyak jelantah didominasi oleh asam lemak tak jenuk ganda (asam linoleat/ $\mathrm{C}_{18-2}$ ), asam lemak tak jenuh tunggal (asam palmitat/ $\mathrm{C}_{16-1}$ dan asam oleat/ $\mathrm{C}_{18-1}$ ) dan asam lemak jenuh (palmitat/ $\mathrm{C}_{16-0}$ dan asam stearat/ $\mathrm{C}_{18-0}$ ). Uji kualitas biodiesel dari minyak jelantah memenuhi standar kualitas biodiesel SNI 7182:2015 untuk parameter densitas, viskositas, angka asam, angka penyabunan, angka iodin dan setana. Tahapan esterifikasi dan netralisasi efektif dalam mereduksi konsentrasi asam lemak bebas minyak jelantah sebelum digunakan pada tahap transesterifikasi dengan katalis abu tongkol jagung.
\end{abstract}

Kata kunci: esterifikasi, netralisasi, alkali, minyak jelantah, biodiesel, abu tongkol jagung

\begin{abstract}
Esterification and deacidification of waste cooking oil using alkali neutralization for biodiesel production using corncob ash as an alternative base catalyst was carried out. This study aimed to attainone of the desired transesterification conditionsby reducing free fatty acids content of waste cooking oil. Esterification was carried out by reacting waste cooking oil and methanol with certain volume ratio and acid catalyst $\left(\mathrm{H}_{2} \mathrm{SO}_{4}\right)$ at $50^{\circ} \mathrm{C}$ for 4 hours. Deacidification was carried out by adding $0.5 \mathrm{~N} \mathrm{NaOH}$ solution (15\% excess alkali) at $60^{\circ} \mathrm{C}$ for 30 minutes. Esterification of waste cooking oil using acid catalyst before transesterification with corn cobs ash catalyst significantly increased the efficiency of free fatty acid conversion $(92.69 \%)$ under volume ratio of $25 \%$ methanol /oil and $0.5 \%$ acid catalyst for 4 hours reaction. Deacidification of esterified oil with FFA content of $2.29 \mathrm{mg} \mathrm{KOH} / \mathrm{g}$ oil through alkali neutralization at $55^{\circ} \mathrm{C}$ using alkaline content of $0.8 \mathrm{~N}$ reduces free fatty acid content to $0.47 \mathrm{mg} \mathrm{KOH} / \mathrm{g}$ oil. Transesterification results showed that biodiesel component of waste cooking oil was dominated by polyunsaturated fatty acids (linoleic acid / $\mathrm{C}_{18-2}$ ), monounsaturated fatty acids (palmitic acid / $\mathrm{C}_{16-1}$ and oleic acid / $\mathrm{C}_{18-1}$ ) and saturated acids (palmitic / $\mathrm{C}_{16-0}$ and stearic acid / $\mathrm{C}_{18-0}$ ). Most of the biodiesel products were similar to those of the diesel physical characters. Biodiesel made of waste cooking oil meets the biodiesel quality standard (SNI 7182: 2015) for such parameters of density, viscosity, acid number, saponification value, iodine number and cetane. Esterification and neutralization process are effective in reducing free fatty acids content of waste cooking oil before being used in transesterification with corn cobs ash catalyst.
\end{abstract}

Keywords: esterification, neutralization, alkali, waste cooking oil, biodiesel, corn cobs ash 


\section{PENDAHULUAN}

Kebutuhan energi masih menjadi salah satu permasalahan yang cukup serius di Indonesia saat ini. Produksi energi yang bersifat terbarukan perlu menjadi pertimbangan untuk mengatasi kondisi tersebut. Biodiesel telah diterima secara global sebagai salah satu pilihan pengganti minyak petroleum diesel tradisional yang dapat diperbaharui dan ramah lingkungan. Biodiesel merupakan mono alkil ester asam lemak rantai panjang yang diturunkan dari bahan baku lemak seperti minyak nabati dan lemak hewani. Meskipun biodiesel memiliki banyak keunggulan dibandingkan dengan petroleum diesel, namun penggunaannya secara komersial kurang berkembang pesat di Indonesia akibat ketidakcukupan raw material. Penggunaan minyak yang merupakan salah satu bahan makanan masih menjadi perdebatan publik. Oleh karena itu perlu adanya penggantian raw material yang bersifat dapat dimakan dengan raw material lain yang berkualitas rendah dan tidak digunakan sebagai bahan makanan, untuk digunakan dalam produksi biodiesel (Borah $d k k ., 2019$ ).

Salah satu jenis minyak nabati yang layak digunakan sebagai raw material biodiesel pengganti bahan mentah dapat dimakan adalah minyak goreng bekas atau minyak jelantah (waste cooking oil). Minyak jelantah merupakan limbah kuliner yang terdiri dari berbagai jenis minyak goreng bekas pemakaian yang mengandung senyawasenyawa yang bersifat karsinogenik, sehingga penggunaan minyak jelantah yang berkelanjutan berdampak negatif pada kesehatan manusia. Minyak jelantah tersedia dalam jumlah yang melimpah, lebih murah dan mudah diperoleh dari masyarakat. Pemanfaatan minyak jelantah sebagai sumber alternatif bahan baku biodiesel erat kaitannya dengan biaya produksi dan harga raw material yang tinggi.Pengolahan biodiesel dari minyak jelantah merupakan langkah yang efektif untukmengurangi dampak buruk minyak jelantah terhadap manusia dan lingkungan; menurunkan harga bahan mentah biodiesel; serta dapat meningkatkan sustainabilitas produksi biodiesel dengan mengurangi konsumsi sumber bahan mentah dapat dimakan (Chai $d k k ., 2014)$.

Minyak jelantah mengandung asam lemak bebas (Free Fatty Acid/FFA) yang lebih tinggi dibandingkan dengan minyak nabati murni. Konsentrasi asam lemak bebas dan kelembaban merupakan parameter utama dalam menentukan viabilitas minyak nabati yang digunakan dalam proses transesterifikasi. Kandungan air dalam minyak dapat mengakselerasi reaksi hidrolisis minyak sehingga akan mereduksi pembentukan alkil ester secara simultan. Untuk dapat memperoleh rendemen biodiesel sebesar 90\%, kandungan air dalam minyak tidak boleh melebihi $0,5 \%$. Selain itu kandungan asam lemak bebas yang tinggi cenderung mengarahkan reaksi ke reaksi saponifikasi yang menghasilkan sabun dan air dengan adanya katalis basa (Gnanaprakasam $d k k$., 2013). Oleh karena itu kandungan asam lemak bebas perlu dipisahkan sebelum proses transesterifikasi.

Asam lemak bebas pada minyak jelantah diesterifikasi dengan metanol menggunakan katalis asam menghasilkan ester dan air, selanjutnya trigliserida ditransesterifikasi dengan menggunakan abu tongkol jagung sebagai katalis basa. Transesterifikasi minyak jelantah dapat dilakukan apabila bilangan asam minyak kurang dari $1 \mathrm{mg} \mathrm{KOH} / \mathrm{gr}$ minyak. Persentase FFA yang tinggi dalam minyak tidak dapat direduksi dengan proses esterifikasi satu tahap. Esterifikasi dua tahap dibutuhkan untuk dapat mengurangi konten FFA hingga $2 \mathrm{mg} \mathrm{KOH/gr} \mathrm{minyak} \mathrm{(Ghadge} \mathrm{\&}$ Raheman, 2005). Penelitian lain menunjukkan bahwa setelah proses pencucian minyak hasil esterifikasi satu tahap dengan $\mathrm{NaOH} 1 \mathrm{~N}$, kandungan asam lemak bebas masih berada pada level yang lebih tinggi dari $1,5 \mathrm{mg}$ $\mathrm{KOH} / \mathrm{gr}$ minyak (Park $d k k$., 2010). Untuk itu diperlukan proses tambahan untuk mengurangi kandungan FFA hinga 0,5 mg KOH/gr minyak. Pada penelitian ini dilakukan esterifikasi minyak jelantah yang dilanjutkan dengan proses netralisasi alkali untuk mengurangi kandungan asam berlebih dari minyak hasil esterifikasi. Hasil esterifikasi dengan kandungan FFA lebih kecil dari $1 \mathrm{mg}$ $\mathrm{KOH} / \mathrm{gr}$ minyak dilanjutkan dengan transesterifikasi menggunakan abu tongkol jagung (ATJ) menghasilkan biodiesel.

\section{MATERI DAN METODOLOGI}

\section{Bahan}

Bahan-bahan yang digunakan pada penelitian ini yaitu $\mathrm{H}_{2} \mathrm{SO}_{4}$, etanol, metanol 
(p.a), $\mathrm{KOH}, \mathrm{NaOH}, \mathrm{KOH}, \mathrm{Na}_{2} \mathrm{SO}_{4}$ anhidrat p.a (Merck), indikator fenolftalein, aquades dan abu tongkol jagung yang dibuat sendiri.

\section{Alat}

Peralatan yang digunakan terdiri dari seperangkat alat gelas, satu set alat refluks (labu leher tiga kapasitas $500 \mathrm{~mL}$, termometer, pengaduk magnet, pemanas listrik, sistem pendingin), stopwatch, timbangan elektrik, oven, corong pisah, sentrifuge, GC-MS (Shimadzu QP-2010S).

\section{Cara Kerja}

\section{Preparasi Minyak Jelantah (MJ)}

Minyak jelantah diperoleh secara random dari beberapa tempat penjualan gorengan yang tersebar dibeberapa titik di Kelurahan Oebufu, Kecamatan Oebobo, Kota Kupang. Sampel minyak jelantah diambil pada penggorengan ke I, II, dan III. Minyak jelantah yang telah dikumpulkan, disaring untuk menghilangkan pengotor-pengotor tidak terlarut dan dipanaskan pada suhu $110^{\circ} \mathrm{C}$ untuk menghilangkan konten air. Penentuan kadar FFA pada tiap-tiap sampel dilakukan dengan metode titrimetri. Sampel ditimbang sebanyak 2,5 gram, ditambahkan 12,5 mL etanol $95 \%$, kemudian dipanaskan selama 10 menit diatas penangas air sambil diaduk dan ditutup dengan pendingin balik hingga dingin, kemudian dititrasi dengan $\mathrm{KOH}$ 0,1M menggunakan indikator phenolptalein sampai tepat berwarna merah muda yang tidak hilang selama 30 detik.Konten FFA untuk tiap-tiap sampel dihitung dengan Persamaan (1):

Bilangan Asam $=\frac{V K O H \times M K O H \times 56,1}{\text { Bobot Sampel }(g)}$

Sampel dengan konten FFA $>1$ mg $\mathrm{KOH} /$ gminyak dilanjutkan dengan esterifikasi dan netralisasi, sedangkan sampel dengan konten FFA $<1$ g KOH/g minyak dilanjutkan dengan transesterifikasi.

\section{Esterifikasi dan Netralisasi}

Esterifikasi minyak jelantah dilakukan dengan mereaksikan $50 \mathrm{~mL}$ minyak jelantah dengan $10 \%$ metanol dan $0,4 \%$ katalis asam $\left(\mathrm{H}_{2} \mathrm{SO}_{4}\right)$ dalam labu leher tiga yang dilengkapi dengan stirrer dan inlet termometer. Reaksi dilakukan pada suhu $50^{\circ} \mathrm{C}$ selama 4 jam. Setelah reaksi esterifikasi selesai, lapisan minyak diambil dan dicuci dengan air destilasi sebanyak tiga kali. Konten air dihilangkan melalui vakum evaporator kemudian konversi FFA ditentukan dengan perhitungan:

Konversi $F F A(\%)=\frac{A i-A t}{A i} \times 100$

Dimana $A_{i}$ dan $A_{t}$ merupakan keasaman awal/mula-mula (i) dan keasaman pada waktu t.

Parameter-parameter yang mempengaruhi esterifikasi seperti rasio metanol/minyak, konsentrasi katalis asam dan waktu reaksidioptimasi.

Sampel minyak jelantah hasil esterifikasi dilanjutkan dengan proses deasidifikasi (netralisasi alkali)didalam labu leher tiga yang dilengkapi dengan magnetic stirer dan termometer. Sampel minyak jelantah $20 \mathrm{~g}$ dicampur dengan larutan $\mathrm{NaOH}$ 0,5 N (alkali berlebih sebanyak $15 \%$ ) pada suhu $60^{\circ} \mathrm{C}$ selama 30 menit. Setelah reaksi selama 30 menit, ditambahkan air destilasi dengan suhu $60^{\circ} \mathrm{C}$ dan $5 \%$ berat minyak untuk mempercepat koagulasi dan sedimentasi. Larutan sabun disentrifugasi pada $6000 \mathrm{rpm}$ untuk menghilangkan sabun. Lapisan minyak dicuci dengan air destilasi kemudian dikeringkan dengan vakum. Laju deasidifikasi FFA minyak dihitung dengan persamaan berikut:

$\delta(\%)=\frac{s p-s d}{s p} \times 100 \%$

dimana $\delta$ merupakan laju penghilangan FFA, $\mathrm{Sp}=$ bilangan asam pada esterifikasi (mg $\mathrm{KOH} / \mathrm{g}$ ), $\mathrm{Sd}=$ Bilangan asam pada hasil netralisasi (mg KOH/g). Parameter yang dioptimasi adalah konsentrasi alkali

\section{Transesterifikasi}

Transesterifikasi minyak jelantah dilakukan dengan mereaksikan $50 \mathrm{~g}$ minyak jelantah dan $75 \mathrm{~mL}$ larutan metanol-abu tongkol jagung $5 \mathrm{~g}$ yang telah dipreparasi sebelumnya di dalam labu leher tiga selama 2 jam pada suhu $60^{\circ} \mathrm{C}$ sambil diaduk. Setelah reaksi berjalan 2 jam, campuran yang terbentuk dituang dalam corong pisah, dibiarkan terjadi pemisahan selama 2 jam pada temperatur kamar. Lapisan metil ester yang terbentuk dipisahkan dari lapisan gliserol, selanjutnya didistilasi sampai temperatur $74{ }^{\circ} \mathrm{C}$ untuk menghilangkan sisa 
metanol. Penghilangan sisa katalis dan gliserol dalam metil ester dilakukan dengan pencucian menggunakan air secara berulang hingga diperoleh lapisan air jernih. Kemudian metil ester dikeringkan dengan penambahan $\mathrm{Na}_{2} \mathrm{SO}_{4}$ anhidrat.

\section{Analisis Biodiesel}

Komposisi metil ester hasil esterifikasinetralisasi dan transesterifikasi dianalisis menggunakan kromatografi gas-spektrometer massa (GC-MS). Kualitas biodiesel diuji dengan metode uji ASTM D 664untuk bilangan asam dan SNI 7182:2015.

\section{HASIL DAN PEMBAHASAN}

\section{Esterifikasi dan Netralisasi}

Minyak jelantah pada penelitian ini diambil secara random pada empat titik di wilayah Kelurahan Oebufu. Hasil analisis kandungan FFA pada setiap pengulangan penggorengan ditunjukkan pada gambar 1 berikut:

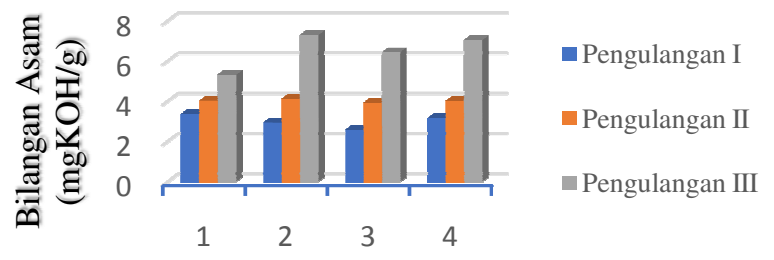

Titik Pengambilan Sampel

Gambar 1. Kandungan asam lemak bebas minyak jelantah

Kandungan asam lemak bebas minyak jelantah pada lokasi pengambilan sampel titik 1, 2, 3 dan 4 berada pada kisaran 2,59-7,04 mg $\mathrm{KOH} / \mathrm{g}$ minyak. Kandungan asam lemak bebas ini termasuk dalam kategori minyak dengan kandungan asam lemak tinggi ( $>1 \mathrm{mg} \mathrm{KOH} / \mathrm{g}$ minyak) sehingga tidak dapat digunakan langsung pada transesterifikasi menggunakan katalis basa (Ding $d k k$., 2012). Penggunaan minyak nabati dengan kandungan asam lemak bebas tinggi pada transesterifikasi cenderung mengarah ke reaksi samping seperti saponifikasi yang menghasilkan sabun dan air. Produk air dari saponifikasi akan menghidrolisis trigliserida menjadi asam lemak bebas yang lebih banyak (Gnanaprakasam dkk., 2013). Data Gambar 1 menunjukkan bahwa penggorengan berulang sebanyak tiga kali meningkatkan jumlah asam lemak bebas dalam minyak jelantah. Kenaikan persentase asam lemak bebas terjadi karena reaksi hidrolisis trigliserida akibat adanya kelembaban dan reaksi oksidasi (Berchmans \& Hirata, 2008).

\section{Pengaruh Rasio metanol/MJ terhadap Esterifikasi}

Rasio metanol/minyak merupakan salah satu parameter utamayang selalu memiliki pengaruh positif dalam konversi biodiesel. Untuk mempelajari pengaruh rasio metanol/minyak terhadap esterifikasi pada penelitian ini dilakukan melalui variasi metanol/minyak 5, 15, 25, dan $35 \%(\mathrm{v} / \mathrm{v})$. Hasil yang diperoleh ditampilkan dalam Gambar 2.

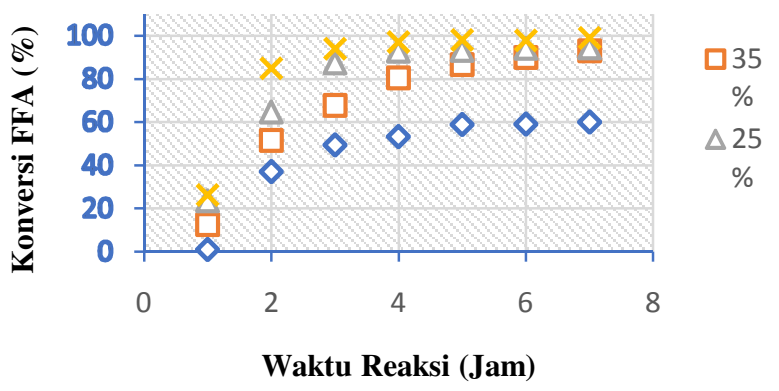

Gambar 2. Pengaruh rasio metanol/minyak
terhadap esterifikasi

Terdapat kenaikan konversi kandungan asam lemak bebas menjadi metil ester seiring dengan bertambahnya rasio metanol terhadap minyak. Pada penelitian ini, kandungan asam lemak bebas tereduksi secara signifikan pada rasio metanol/minyak $15-35 \%$. Secara teori satu mol metanol dibutuhkan untuk bereaksi dengan satu mol minyak menghasilkan ester dan air. Namun secara praktek reaksi esterifikasi membutuhkan metanol berlebih untuk dapat menggeser reaksi kearah pembentukan metil ester (Sadaf $d k k$., 2018). Konversi asam lemak bebas mengalami kenaikan dari $80,36 \%$ menjadi $92,69 \%$ seiring dengan kenaikan rasio metanol minyak dari 15 menjadi 25\% setelah 4 jam reaksi dan penggunaan katalis asam $0,4 \%$ pada suhu $50^{\circ} \mathrm{C}$. Kenaikan rasio metanol minyak dari 25 menjadi $35 \%$ meningkatkan persen konversi asam lemak bebas sebesar 4,25\%. Kenaikan rasio metanol/minyak dari $25 \%-35 \%$ tidak meningkatkan persentase konversi asam lemak bebas secara signifikan. Rasio volume metanol/minyak optimum pada penelitian ini 
adalah pada penggunaan rasio $25 \%$. Hal ini mendekati hasil penelitian yang dilakukan Ding dkk. (2012) yang memperoleh kondisi optimum reaksi esterifikasi minyak jelantah pada rasio volume metanol/minyak $20 \%$.

\section{Pengaruh Konsentrasi Katalis Terhadap Esterifikasi}

Pengaruh konsentrasi katalis asam terhadap esterifikasi dipelajari dengan melakukan variasi konsentrasi katalis asam 0,$1 ; 0,3 ; 0,5$; 0,7; dan 0,9\%. Konsentrasi katalis pada penelitian ini merupakan fraksi volume minyak dalam campuran reaksi. Pengaruh jumlah katalis terhadap efisiensi konversi FFA diilustrasikan pada Gambar 3. Pada Gambar 3 terjadi kenaikan persen konversi FFA dari $60,99 \%$ menjadi $81,55 \%$ ketika konsentrasi katalis asam dinaikkan dari 0,1 menjadi 0,3\% setelah esterifikasi selama 4 jam pada suhu $50^{\circ} \mathrm{C}$ dengan rasio volume metanol/minyak $25 \%$. Penggunaan konsentrasi asam lebih dari $0,5 \%$ sedikit meningkatkan konversi asam lemak (2-4\%). Esterifikasi tanpa menggunakan katalis asam selama 6 jam hanya meningkatkan konversi asam lemak bebas sebanyak $4,7 \%$, penambahan katalis asam sebanyak $0,5 \%$ meningkatkan persentase konversi metil ester menjadi $76 \%$, penambahan konsentrasi katalis asam hingga $1 \%$ meningkatkan persen konversi menjadi $83,7 \%$ (Sadaf $d k k ., 2018$ ). Variasi konsentrasi katalis asam yang digunakan pada penelitian ini mencapai kondisi optimum pada konsentrasi $0,5 \%$.

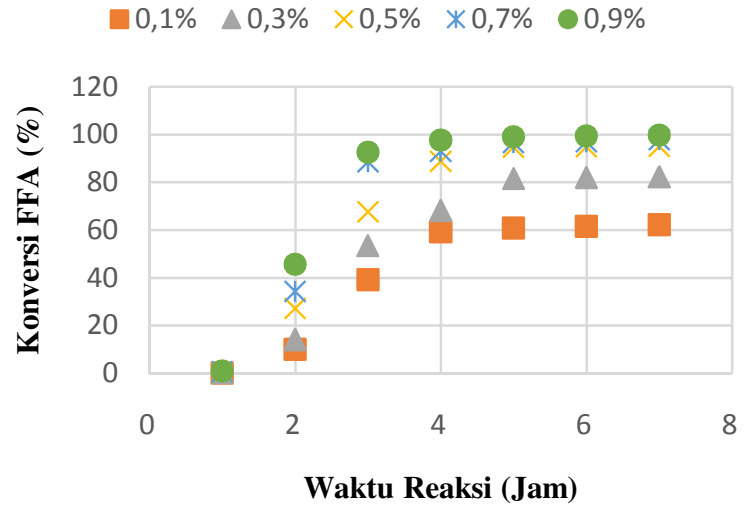

Gambar 3. Pengaruh Konsentrasi katalis asam terhadap esterifikasi

\section{Pengaruh Konsentrasi Alkali terhadap Netralisasi}

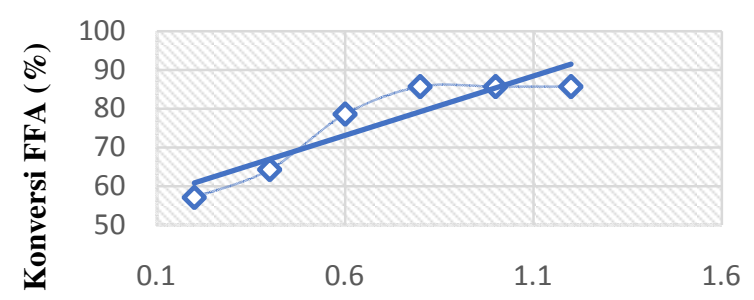

Konsentrasi Alkali (N)

\section{Gambar 4. Pengaruh Konsentrasi Alkali} Terhadap Netralisasi

Minyak hasil esterifikasi memiliki kandungan FFA rata-rata $1,52 \mathrm{mg} \mathrm{KOH} / \mathrm{g}$ minyak sehingga belum memenuhi standar untuk transesterifikasi dengan katalis basa. Tahapan perlakuan netralisasi alkali untuk mereduksi kandungan FFA hingga lebih kecil dari $1 \mathrm{mg} \mathrm{KOH} / \mathrm{g}$ minyak perlu dilakukan. Netralisasi asam lemak bebas pada minyak esterifikasi menggunakanNaOH dengan konsentrasi yang divariasikan pada range 0,21,2 N. Pengaruh konsentrasi alkali terhadap konversi asam lemak bebas pada proses netralisasi ditampilkan pada Gambar 4. Efisiensi konversi asam lemak bebas maksimum dicapai pada penggunaan konsentrasi alkali 0,8 N. Konsentrasi alkali yang lebih besar dari $0,8 \mathrm{~N}$ tidak meningkatkan persen konversi. Laju konversi asam lemak bebas menjadi lambat akibat luas permukaan kontak antara alkali dengan asam lemak bebas berkurang. Penggunaan konsentrasi alkali yang sangat rendah tidak efektif dalam pembentukan sabun, menyebabkan pemisahan antara produk sabun dan minyak dari sistem menjadi lebih sulit. Di sisi lain penggunaan alkali yang berlebihan dapat memicu terjadinya reaksi alkali dengan minyak netral yang berakibat pada berkurangnya produk minyak esterifikasi (Ding $d k k ., 2012$ ).

\section{Pengaruh Suhu Terhadap Netralisasi}

Suhu merupakan salah satu parameter yang memiliki pengaruh signifikan pada proses deasidifikasi minyak hasil esterifikasi. Pada penelitian ini, pengaruh suhu diamati dengan melakukan variasi suhu pada $25,35,45,55,65$ dan $75^{\circ} \mathrm{C}$ dengan konsentrasi $\mathrm{NaOH} 0,8 \mathrm{~N}$. 


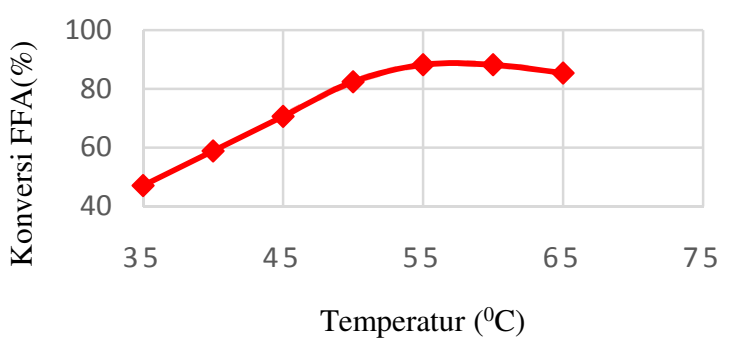

Gambar 5. Pengaruh suhu terhadap netralisasi

Gambar 5 menunjukkan bahwa laju konversi FFA mengalami kenaikan seiring dengan bertambahnya suhu sistem. Konversi FFA mengalami kenaikan secara proporsional pada suhu 50 dan $55^{\circ} \mathrm{C}$ yaitu sebesar 82,35 dan $88,23 \%$. Penggunaan suhu yang lebih tinggi dari $60^{\circ} \mathrm{C}$ menurunkan persen konversi FFA, sebagai akibat dari dekomposisi metil ester dan trigliserida pada suhu tinggi (Ding $d k k$., 2012).

\section{Analisis Hasil Transesterifikasi}

Reaksi transesterifikasi minyak jelantah dilakukan pada temperatur $60^{\circ} \mathrm{C}$, dengan menggunakan katalis basa $\mathrm{K}_{2} \mathrm{CO}_{3}$ yang berasal dari abu tongkol jagung sebanyak $5 \mathrm{~g}$ di dalam media metanol dengan rasio metanol/minyak 6:1 selama dua jam, diperoleh konversi biodiesel sebesar 99,03\%. Komponen metil ester hasil transesterifikasi dianalisis dengan GC-MS, diperoleh kromatogram pada Gambar 6.

Data MS menunjukkan bahwa hasil transesetrifikasi pada penelitian ini merupakan senyawa metil ester. Komponen metil ester yang terdapat pada kromatogram tersebut dirangkum dalam Tabel 1.

Tabel 1.Komponen Metil Ester

\begin{tabular}{|c|c|c|c|}
\hline Nama Senyawa & $\begin{array}{l}\text { Waktu } \\
\text { Retensi }\end{array}$ & Puncak & $\begin{array}{c}\text { Luas } \\
\text { Puncak }(\%)\end{array}$ \\
\hline Metil linoleat & 23,767 & 6 & 32,12 \\
\hline Metil palmitat & $\begin{array}{l}21,741 \\
\& \quad 21860\end{array}$ & $4 \& 5$ & $\begin{array}{l}17,58 \\
15,92\end{array}$ \\
\hline Metil oleat & 23,921 & 7 & 14,35 \\
\hline Metil stearat & 24,064 & 8 & 10,16 \\
\hline Metil miristat & 19,439 & 3 & 3,01 \\
\hline Metil arakidat & 26,884 & 11 & 1,56 \\
\hline Metil laurat & 16,898 & 2 & 0,47 \\
\hline Metil kaprilat & 10,274 & 1 & 0,30 \\
\hline $\begin{array}{l}\text { Metil cis-9,10- } \\
\text { epoksistearat }\end{array}$ & 26,187 & 9 & 1,35 \\
\hline $\begin{array}{l}\text { Metil trans-9,10- } \\
\text { epoksistearat }\end{array}$ & 26,542 & 10 & 2,21 \\
\hline
\end{tabular}

Biodiesel dari minyak jelantah merupakan konversi dari asam lemak jenuh rantai pendek seperti asam laurat $\left(\mathrm{C}_{12-0}\right)$ dan asam kaprilat $\left(\mathrm{C}_{10-0}\right)$ sebesar 0,47 dan 0,30 \%; asam lemak jenuh rantai panjang diantaranya asam miristat $\left(\mathrm{C}_{14-0}\right)$, asam palmitat $\left(\mathrm{C}_{16-0}\right)$, asam stearat $\left(\mathrm{C}_{18-}\right.$ $\left.{ }_{0}\right)$ dan asam arakidat $\left(\mathrm{C}_{20-0}\right)$ secara berturutturut sebesar 3,01; 17,58; 10,16; dan 1,56\%. Biodiesel juga mengandung asam lemak tak jenuh tunggal seperti asam palmitat $\left(\mathrm{C}_{16-1}\right)$ dan asam oleat $\left(\mathrm{C}_{18-1}\right)$ sebesar 15,92 dan $14,35 \%$; dan asam lemak tak jenuh ganda yaitu asam linoleat $\left(\mathrm{C}_{18-2}\right)$ sebesar 32,12\%.

Komposisi asam lemak pada Tabellmengindikasikan bahwa minyak jelantah yang digunakan pada pembuatan biodiesel merupakan jenis minyak kelapa. Terdapat komponen lain seperti metil cis-9,10epoksistearat dan metil trans-9,10epoxystearat yang tidak sesuai dengan kandungan asam-asam lemak pada minyak kelapa. Senyawa yang tidak sesuai diduga berasal dari hasil transesterifikasi asam lemak yang berasal dari bahan makanan yang digoreng maupun hasil reaksi oksidasi ikatan rangkap pada asam lemak tak jenuh oleh oksigen aktif membentuk senyawa epoksida akibat proses penggorengan menggunakan minyak secara berulang. Proses penggorengan yang berulang-ulang pada suhu yang tinggi, dapat menyebabkan terjadinya perubahan geometris pada asam-asam lemak tak jenuh menjadi isomernya yaitu asam lemak trans akibat proses oksidasi (Sartika, 2010). Perubahan geometris asam-asam lemak tak jenuh menurunkan kualitas minyak dan makanan. Oleh karena itu penggunaan kembali minyak tidak disarankan karena terjadi daur ulang senyawa berbahaya yangdapat menambah resiko buruk terhadap kesehatan manusia (Phan \& Phan, 2008).

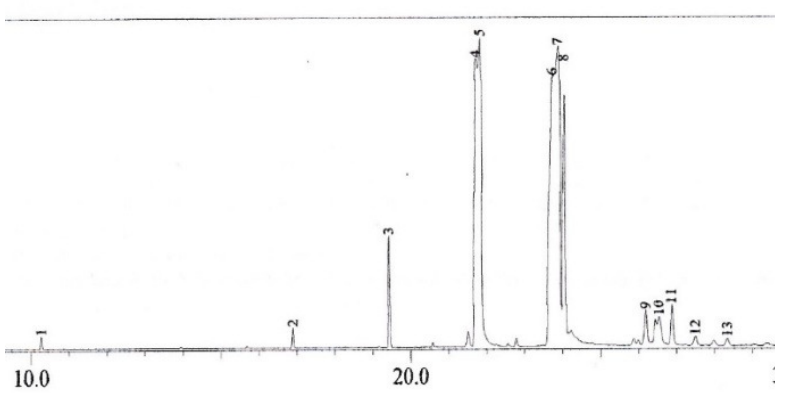

Gambar 6. Kromatogram Biodiesel Minyak Jelantah 


\section{Uji Kualitas Biodiesel}

Sifat-sifat biodiesel sebagai bahan bakar diukur dan dibandingkan terhadap standar kualitas biodiesel menurut SNI 7182:2015. Hasil yang diperoleh ditampilkan pada Tabel 2.

Tabel 2.Karakteristik Biodiesel yang dibuat dari Minyak Jelantah

\begin{tabular}{|c|c|c|c|}
\hline Sifat & Satuan & $\begin{array}{c}\text { Biodiesel } \\
\text { dari } \\
\text { Minyaka } \\
\text { Jelantah }\end{array}$ & $\begin{array}{c}\text { Standar } \\
\text { SNI } \\
\text { 7182:2015 }\end{array}$ \\
\hline Densitas & $\mathrm{g} / \mathrm{mL}$ & 0,880 & $\begin{array}{c}0,850- \\
0,890\end{array}$ \\
\hline Viskositas & $\mathrm{cSt}\left(\mathrm{mm}^{2} / \mathrm{s}\right)$ & 3,83 & $2,3-6,0$ \\
\hline $\begin{array}{l}\text { Angka } \\
\text { asam }\end{array}$ & $\underset{\text { minyak }}{\mathrm{mg} \mathrm{KOH} / \mathrm{g}}$ & 0,42 & $<0,5$ \\
\hline $\begin{array}{l}\text { Angka } \\
\text { Penyabunan }\end{array}$ & $\underset{\text { minyak }}{\mathrm{mg} \mathrm{KOH} / \mathrm{g}}$ & 55,23 & $<312$ \\
\hline $\begin{array}{l}\text { Bilangan } \\
\text { Iodin }\end{array}$ & $\begin{array}{c}\mathrm{gr} \mathrm{I}_{2} / 100 \mathrm{~g} \\
\text { minyak }\end{array}$ & 76,14 & $<115$ \\
\hline $\begin{array}{l}\text { Angka } \\
\text { setana }\end{array}$ & - & 130,02 & $>51$ \\
\hline
\end{tabular}

Sifat-sifat biodiesel hasil transesterifikasi dari minyak jelantah seperti densitas, viskositas, angka asam, angka penyabunan, bilangan iodin dan angka setana memenuhi standar kualitas biodiesel SNI 7182:2015. Dengan demikian tahapan esterifikasi dan netralisasi alkali efektif dalam meningkatkan kualitas produk transesterifikasi minyak jelantah.

\section{SIMPULAN}

Esterifikasi minyak jelantah menggunakan katalis asam sebelum transesterifikasi dengan katalis abu tongkol jagung meningkatkan efisiensi konversi asam lemak bebas secara signifikan pada kondisi rasio volume metanol/minyak $25 \%$ dan konsentrasi katalis asam $0,5 \%$ selama 4 jam reaksi. Deasidifikasi minyak hasil esterifikasi yang memilikikandunganFFA $\quad 2,29 \mathrm{mg} \quad \mathrm{KOH} / \mathrm{g}$ minyak melalui netralisasi alkali pada suhu $55^{\circ} \mathrm{C}$ menggunakan konsentrasi alkali $0,8 \mathrm{~N}$ menurunkankandungan asam lemak bebas hingga $0,47 \mathrm{mg} \mathrm{KOH} / \mathrm{g}$ minyak. Analisis terhadap hasil transesterifikasi menunjukkan bahwa komponen biodiesel didominasi oleh asam lemak tak jenuk ganda (asam linoleat $/ \mathrm{C}_{18-2}$ ), asam lemak tak jenuh tunggal (asam palmitat/ $\mathrm{C}_{16-1}$ dan asam oleat $/ \mathrm{C}_{18-1}$ ) dan asam lemak jenuh (palmitat/ $\mathrm{C}_{16-0}$ dan asam stearat $/ \mathrm{C}_{18-0}$ ) serta memenuhi standar kualitas biodiesel SNI 7182:2015.

\section{DAFTAR PUSTAKA}

Berchmans, H.J. \& Hirata, S. 2008. Biodiesel production from crude Jatropha curcas L. seed oil with a high content of free fatty acids. Bioresource technology. 99(6): 1716-1721.

Borah, M.J., Das, A., Das, V., Bhuyan, N. \& Deka, D. 2019. Transesterification of waste cooking oil for biodiesel production catalyzed by $\mathrm{Zn}$ substituted waste egg shell derived $\mathrm{CaO}$ nanocatalyst. Fuel. 242: 345-354.

Chai, M., Tu, Q., Lu, M. \& Yang, Y.J. 2014. Esterification pretreatment of free fatty acid in biodiesel production, from laboratory to industry. Fuel processing technology. 125: 106-113.

Ding, J., Xia, Z. \& Lu, J. 2012. Esterification and deacidification of a waste cooking oil (TAN $68.81 \mathrm{mg} \mathrm{KOH} / \mathrm{g}$ ) for biodiesel production. Energies. 5(8): 26832691.

Ghadge, S.V. \& Raheman, H. 2005. Biodiesel production from mahua (Madhuca indica) oil having high free fatty acids. Biomass and Bioenergy. 28(6): 601-605.

Gnanaprakasam, A., Sivakumar, V.M., Surendhar, A., Thirumarimurugan, M. \& Kannadasan, T. 2013. Recent strategy of biodiesel production from waste cooking oil and process influencing parameters: a review. Journal of Energy. 2013.

Park, J.-Y., Wang, Z.-M., Kim, D.-K. \& Lee, J.-S. 2010. Effects of water on the esterification of free fatty acids by acid catalysts. 
Renewable Energy. 35(3): 614618.

Phan, A.N. \& Phan, T.M. 2008. Biodiesel production from waste cooking oils. Fuel. 87(17-18): 3490-3496.

Sadaf, S., Iqbal, J., Ullah, I., Bhatti, H.N., Nouren, S., Nisar, J. \& Iqbal, M. 2018. Biodiesel production from waste cooking oil: an efficient technique to convert waste into biodiesel. Sustainable cities and society. 41: 220-226.

Sartika, R.A.D. 2010. Pengaruh suhu dan lama proses menggoreng (deep frying) terhadap pembentukan asam lemak trans. Makara Journal of Science. 